\title{
Stability of lactoferrin and lysozyme in human milk at various temperatures and duration of storage
}

\author{
Kasiati $^{1^{*}}$, Sumirah Budi Pertami ${ }^{1}$, Agus Setyo Utomo ${ }^{1} \&$ Siti Nur Arifah ${ }^{2}$ \\ ${ }^{1}$ Department of Nursing, Poltekkes Kemenkes Malang, Malang, Indonesia; \\ ${ }^{2}$ Department of Biology, Faculty of Mathematics and Natural Sciences, Universitas \\ Negeri Malang, Malang, Indonesia
}

\begin{abstract}
Introduction: Exclusive breastfeeding, especially in the first six months, is essential for infants as it provides nutrition and protection against various diseases. Colostrum, which is found in the first breast milk produced, contains various protective factors, such as lactoferrin and lysozyme. Human milk can be stored at room temperature, refrigerated, or kept frozen. Several factors affect the stability of the bioactive content in human milk, such as temperature and storage time. The aim of this study was to measure the stability of lactoferrin and lysozyme levels in human milk during the first six hours (h) at different temperatures and compare it with that of frozen human milk. Methods: Human milk samples were obtained from 11 breastfeeding mothers using certain criteria. The human milk was stored at room temperature and $4^{\circ} \mathrm{C}$ for 1,3 , and $6 \mathrm{~h}$ and classified as never frozen, while frozen human milk was stored at $-20^{\circ} \mathrm{C}$ for 1,3 , and 6 days. Measurement of the lactoferrin and lysozyme levels was performed using enzyme-linked immunosorbent assay. Results: The results showed that storage at room temperature significantly reduced lactoferrin and lysozyme levels. Lactoferrin levels in frozen human milk did not significantly decrease during the first six days. Meanwhile, the lysozyme levels in frozen human milk decreased significantly. Conclusion: The levels of lactoferrin and lysozyme in frozen human milk stored for the first six days were more stable than those stored at room temperature and $4^{\circ} \mathrm{C}$ in the first $6 \mathrm{~h}$.
\end{abstract}

Keywords: human milk, lactoferrin, lysozyme, storage duration, temperature

\section{INTRODUCTION}

Breast milk is an important source of nutrition for newborns and infants. According to the World Health Organization (WHO), exclusive breastfeeding for the first six months is essential for infants and is recommended until the age of 2 years (WHO, 2009). The neonatal period is a critical period for an infant due to the susceptibility to various types of antigens, including bacteria and viruses, or others (Lawrence $\&$ Lawrence, 2016). Exclusive breastfeeding protects infants from various diseases, such as otitis media, respiratory tract infections, gastroenteritis, sepsis, childhood cancer, asthma, and meningitis (El-Agamy, 2011; Palmeira et al., 2016; Basir et al., 2019). Human milk contains numerous components of the immune system which are essential and vital for infants (Abdullah \& Saleh, 2019). Colostrum

\footnotetext{
*Corresponding author: Kasiati

Department of Nursing, Poltekkes Kemenkes Malang, Malang, Indonesia

Tel: (62)341) 566075; Fax: (62) 341) 556746; E-mail: kasiati_skep@poltekkes-malang.ac.id doi: https://doi.org/10.31246/mjn-2020-0132
} 
in human milk, which is first produced before birth up to approximately four days postpartum, contains various protective factors, such as enzymes (lactoferrin, lysozyme, and others), immunoglobulin (Ig), especially IgA, cytokines, leukocytes, fats, hormones, and others that contribute to the maturation of the infant's immune system (Kasiati et al., 2013; Palmeira et al., 2016; Basir et al., 2019).

Lactoferrin (Lf) is a glycoprotein from the transferrin protein group with a mass of approximately $78-80 \mathrm{kDa}$ (Lawrence \& Lawrence, 2011), and was first discovered in cow's milk as a red protein in whey (Czosnykowska-Łukacka et al., 2019). Lf has antibacterial (Bruni et al., 2016), antibiotic, and antiviral properties (Berlutti et al., 2011). The geographic location, nutritional status, socioeconomic status, race, genetic polymorphism, birth process, and infant condition determine the Lf levels in human milk (Czosnykowska-Łukacka et al., 2019). Lysozyme is a $14 \mathrm{kDa}$ cationic protein and lytic enzyme. Lysozyme was first discovered by Alexander Fleming in 1921, when droplets from Fleming's nose fell on a petri dish filled with bacteria. Lysozyme is secreted by the mucous glands, neutrophils, and macrophages (Ganz, 2006). Lysozyme is known to have antibacterial activity against both grampositive and gram-negative bacteria (Masschalck \& Michiels, 2003), antiviral activity (Małaczewska et al., 2019), and anti-inflammatory properties (Tagashira et al., 2018).

Human milk is typically given fresh to the infant; however, there are certain situations wherein the human milk cannot be consumed directly by the infant, such as suckling issues of the infant, a wound on the mother's nipple, or mothers returning to work. Therefore, mothers of infants use breast pumps to help collect their milk and store it. Human milk can be stored at room temperature, refrigerated, or frozen. The factors of temperature and storage time of human milk have been determined to affect the bioactive content in human milk, including the levels of lactoferrin and lysozyme. Human milk stored at $-20^{\circ} \mathrm{C}$ for 3 months and six months showed significantly decreased lactoferrin levels up to $37 \%$ and $46 \%$, respectively, compared to fresh human milk (Rollo et al., 2014). Chang et al. (2013) also reported that lysozyme levels significantly decreased to $39.8 \%$ in frozen human milk stored at $-20^{\circ} \mathrm{C}$ for four weeks compared to fresh human milk (Chang et al., 2013). However, there is limited research related to the levels of Lf and lysozyme in fresh human milk at various temperatures and storage times.

The Academy of Breastfeeding Medicine's clinical protocol states that freshly expressed human milk with very low bacterial count can be stored at room temperature for a maximum of 6-8 $\mathrm{h}$ (Eglash et al., 2017). The aim of this study is therefore to provide information about the stability of lactoferrin and lysozyme levels in fresh human milk at different storage times, specifically for the first $6 \mathrm{~h}$, and storage temperatures, as well as compared with frozen breast milk. With clearer information, guidance can be given on the storage condition and duration that can best preserve the bioactive content in human milk to ensure that the infant is provided with optimum nutrition.

\section{METHODS}

\section{Collection of human milk}

Human milk samples were obtained from breastfeeding mothers registered in the Pondok Kesehatan Desa, Sumber Porong, Malang, Indonesia. Eleven breastfeeding mothers were selected by consecutive sampling based on three criteria, namely (i) days 4 to 30 postpartum, (ii) underwent normal 
delivery process, and (iii) in good health. Data related to general characteristics, including age, weight, height, medical records, therapeutic treatment, and pregnancy history were carefully recorded. Data regarding infant's weight and height were recorded. Data consent from breastfeeding mothers had been obtained before samples of human milk were collected. Human milk was collected between 7:00 and 10:00 a.m. using an electric breast pump. All samples were collected in $10 \mathrm{ml}$ sterile bottles. Frozen breast milk was stored at $-20^{\circ} \mathrm{C}$ (freezer) for one, three, and six days. On the $6^{\text {th }}$ day, fresh human milk was collected again and stored for
1,3 , and $6 \mathrm{~h}$ at different temperatures, i.e. room temperature and $4^{\circ} \mathrm{C}$ (Figure 1). This research was approved by the ethics committee of Poltekkes Kemenkes Malang (number 925/KEPKPOLKESMA/2020).

\section{Measurement of lactoferrin and lysozyme levels}

The measurement of $\mathrm{Lf}$ and lysozyme levels in human milk was performed using enzyme-linked immunosorbent assay (ELISA). Liquid human milk was centrifuged at $3000 \mathrm{rpm}$ for 20 minutes at $4^{\circ} \mathrm{C}$. The supernatant was collected for ELISA. The ELISA kits for Lf (Fine Test Biotech, Cat. no. EH0396, China)

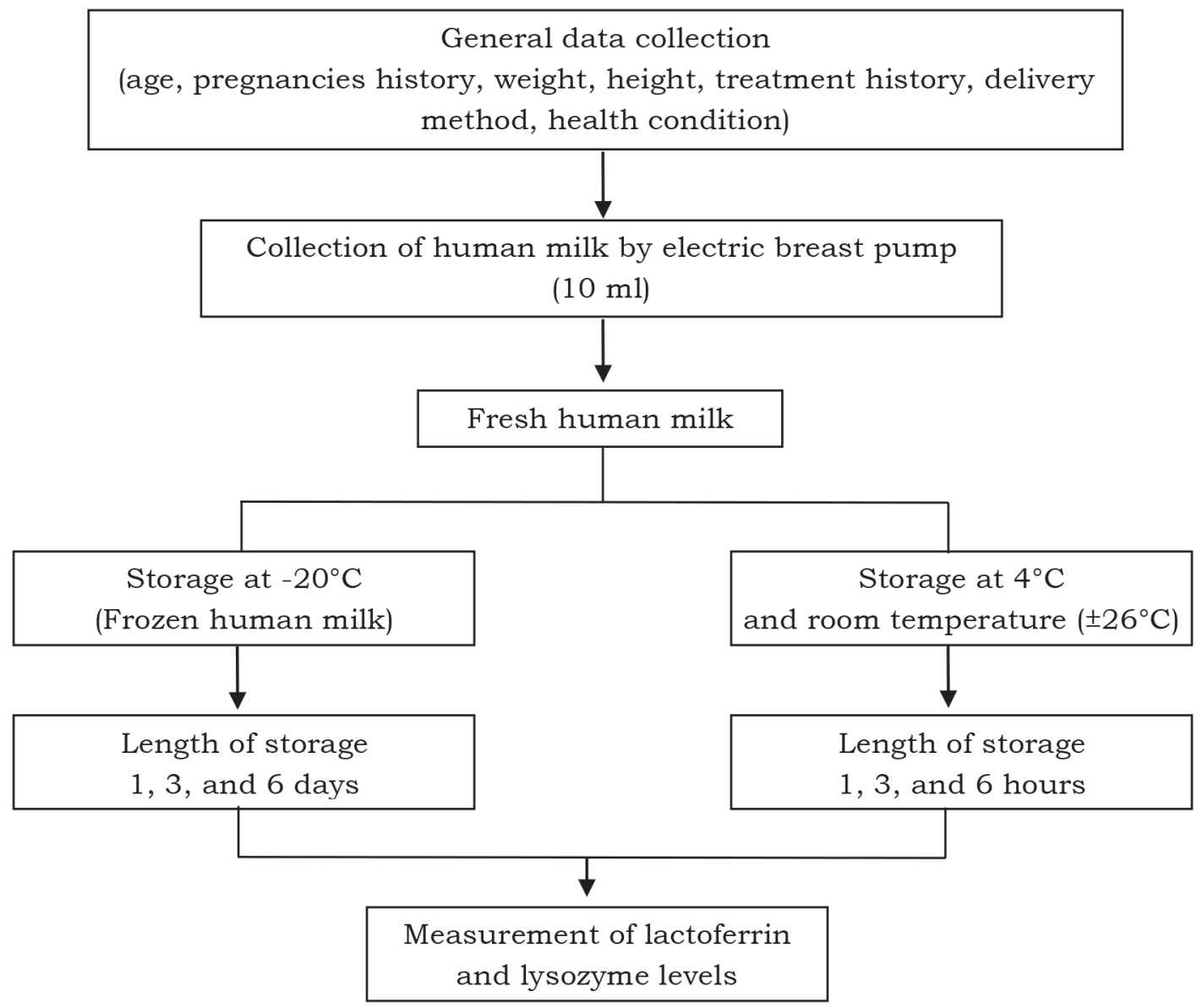

Figure 1. Data collection flow 
and lysozyme (Fine Test Biotech, Cat No. EH3314, China) were used to carry out tests according to the manufacturer's instructions. The Lf and lysozyme levels were measured at a wavelength of 450 nm. A standard curve was used to determine the lactoferrin and lysozyme levels.

\section{Statistical analysis}

Data on Lf and lysozyme levels in human milk were analysed using a two-way analysis of variance (ANOVA) (SPSS 23.0, SPSS Inc., Chicago, IL, USA). The significant differences between groups were analysed by Duncan's multiple range test as a post-hoc test. A $p$-value $<0.05$ was considered as statistically significant.

\section{RESULTS}

The results showed that the levels of Lf in human milk stored at room temperature in the first $6 \mathrm{~h}$ decreased significantly $(p<0.05)$ compared to those stored at $4{ }^{\circ} \mathrm{C}$ and frozen (Figure 2). The lowest level of lactoferrin was observed upon $6 \mathrm{~h}$ of storage at room temperature. Storage at $4^{\circ} \mathrm{C}$ for 3 and $6 \mathrm{~h}$ decreased the level of lactoferrin compared with frozen human milk. Based on these results, the lactoferrin levels were more stable at cold temperatures and were significantly decreased after the first $3 \mathrm{~h}$ of storage at room temperature.

The results showed that the lysozyme levels at room temperature were significantly reduced compared to those in frozen human milk $(p<0.05)$ (Figure 3). Frozen human milk stored for the first six days was observed to have a significantly decreased lysozyme level after storage for three and six days $(p<0.05)$. Frozen human milk stored for one day had the highest levels of lysozyme.

\section{DISCUSSION}

Human milk provides the essential nutritional standards for newborns and infants. Lf and lysozyme are the enzymes present in human milk, which play a role in the immune system of infants. Lactoferrin and lysozyme levels in breast milk can decrease due to changes in the environment. The protein aggregation in lactoferrin and lysozyme is induced by several conditions, such as changes in $\mathrm{pH}$ that are too acidic or alkaline, a dramatic increase or decrease in the

Table 1. General information of mothers and infants

\begin{tabular}{ccccccc}
\hline Donors & $\begin{array}{c}\text { Age } \\
\text { (years) }\end{array}$ & $\begin{array}{c}\text { Previous } \\
\text { pregnancies }\end{array}$ & $\begin{array}{c}\text { Weight }(\mathrm{kg}) / \\
\text { Height }(\mathrm{cm})\end{array}$ & $\begin{array}{c}\text { Body Mass } \\
\text { Index }(\mathrm{BMI}) \\
\left(\mathrm{kg} / \mathrm{m}^{2}\right)\end{array}$ & $\begin{array}{c}\text { BMI } \\
\text { category }\end{array}$ & $\begin{array}{c}\text { Newborns' weight } \\
(\mathrm{kg}) / \text { length }(\mathrm{cm})\end{array}$ \\
\hline A & 31 & 1 & $55.0 / 150$ & 24.44 & normal & $3.4 / 49$ \\
B & 25 & - & $65.0 / 158$ & 26.04 & overweight & $3.2 / 51$ \\
C & 31 & 3 & $53.0 / 151$ & 23.24 & normal & $2.7 / 50$ \\
D & 38 & 1 & $60.5 / 160$ & 23.63 & normal & $3.0 / 48$ \\
E & 26 & 2 & $49.5 / 149$ & 22.30 & normal & $3.0 / 48$ \\
F & 38 & 1 & $61.0 / 163$ & 22.96 & normal & $3.5 / 51$ \\
G & 33 & 1 & $56.0 / 160$ & 21.88 & normal & $3.7 / 53$ \\
H & 33 & 2 & $60.0 / 150$ & 26.67 & overweight & $2.9 / 49$ \\
I & 34 & 2 & $68.0 / 158$ & 27.24 & overweight & $3.3 / 54$ \\
J & 28 & 2 & $58.0 / 152$ & 25.10 & overweight & $3.9 / 48$ \\
K & 35 & 2 & $60.0 / 154$ & 25.30 & overweight & $3.1 / 49$ \\
\hline
\end{tabular}


temperature, and high concentrations of organic/inorganic salts (Venkataramani et al., 2013; Wang et al., 2019). The results showed that storage of human milk at room temperature caused a significant reduction in the lactoferrin levels in the first $3 \mathrm{~h}$ of storage. Storage at $4^{\circ} \mathrm{C}$ for $1 \mathrm{~h}$ and frozen breast milk maintained the levels of Lf. However, the lactoferrin levels began to decrease after storage for $3 \mathrm{~h}$ at $4^{\circ} \mathrm{C}$. Meanwhile, the level of lysozyme in human milk stored at room temperature was significantly lower than that in frozen breast milk. The lowest lysozyme level in human milk was found in samples stored at room temperature. Howland et al. (2020) reported cleavage in the peptide structure of the amino acid lysine, arginine, and glutamate due to an increased thrombin activity and other protease enzymes in human milk stored at room temperature. Lysozyme or muramidase is a part of group of glycosidic hydrolases with $14.7 \mathrm{kDa}$ of atomic mass in human lysozyme. Furthermore, aspartate-52 and glutamate- 35 amino acid play a role in enzymatic activity of human lysozyme (Gálvez-Iriqui et al, 2020). The cleavage mechanism in those amino acid might be associated with lysozyme reduction in human milk.

The lactoferrin levels in the first month of lactation are known to decrease, but remain stable subsequently for up to eight months (Affolter et al., 2016; Yang et al., 2018). The lactoferrin levels in colostrum can reach up to $5.5 \mathrm{~g} / \mathrm{L}$, while in mature breast milk lactoferrin levels are only 1.5-3.0g/L (CzosnykowskaLukacka et al., 2019). The lactoferrin in cow's milk is 1.5-2 times lower than the lactoferrin in human milk (Soboleva et al., 2019), that is up to $1.5 \mathrm{mg} / \mathrm{L}$ in colostrum and $0.5 \mathrm{mg} / \mathrm{L}$ in mature cow's milk (Yang et al., 2018). The lysozyme

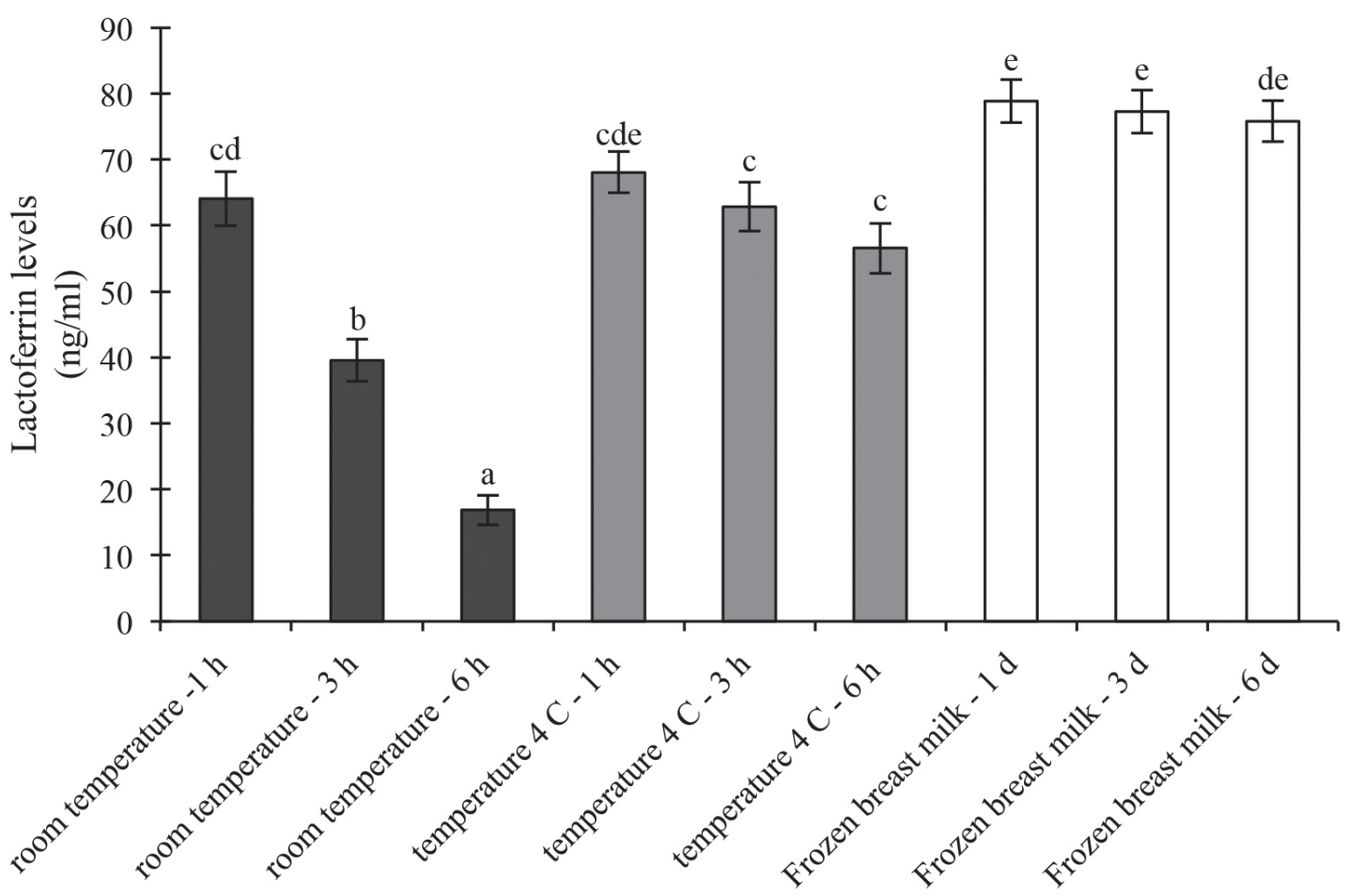

Figure 2. The levels of lactoferrin in human milk at different temperatures and duration of storage times. Different letters showed significant difference compared to other groups based on the DMRT post-hoc test. 
levels in human milk are commonly about $60-400 \mu \mathrm{g} / \mathrm{ml}$ (Yang et al., 2011; Chang et al., 2013) and higher than in cow's milk, which is found to be only $0.05-0.22 \mu \mathrm{g} / \mathrm{ml}$ (Yang et al., 2011). Chang et al. (2013) reported that frozen and pasteurised human milk produced lower lysozyme levels than fresh human milk while the level of freshly expressed human milk is up to $60 \mu \mathrm{g} / \mathrm{mL}$ while frozen human milk only up to $40 \mu \mathrm{g} / \mathrm{mL}$. The proteins in lysozyme can undergo denaturation at either high or low temperatures, depending on the length of storage.

The Australian Breastfeeding Association (ABA) recommends storing fresh human milk at room temperature $\left(\leq 26^{\circ} \mathrm{C}\right)$ for $6-8 \mathrm{~h}$ (Australian Breastfeeding Association, 2011). Eglash et al. (2017) stated that human milk can only be stored at room temperature $\left(10-29^{\circ} \mathrm{C}\right)$ for $6-8 \mathrm{~h}$, depending on the conditions and hygiene of the storage area. This has an impact on the bacterial growth development in human milk during storage. Rollo et al. (2014) reported that the Lf levels in human milk were more stable during storage at $-20^{\circ} \mathrm{C}$ during a five-day period. However, storage at $-20^{\circ} \mathrm{C}$ for a week causes a significant decrease in the macronutrients of human milk compared to fresh human milk (Kim et al., 2019); and if continued until three months of storage, this increases the acidity of human milk (Vázquez-Román et al., 2016). Based on this research, the recommended duration for storage of frozen human milk is not $>6$ days, while fresh human milk can only be stored at room temperature and $4^{\circ} \mathrm{C}$ for $<3 \mathrm{~h}$.

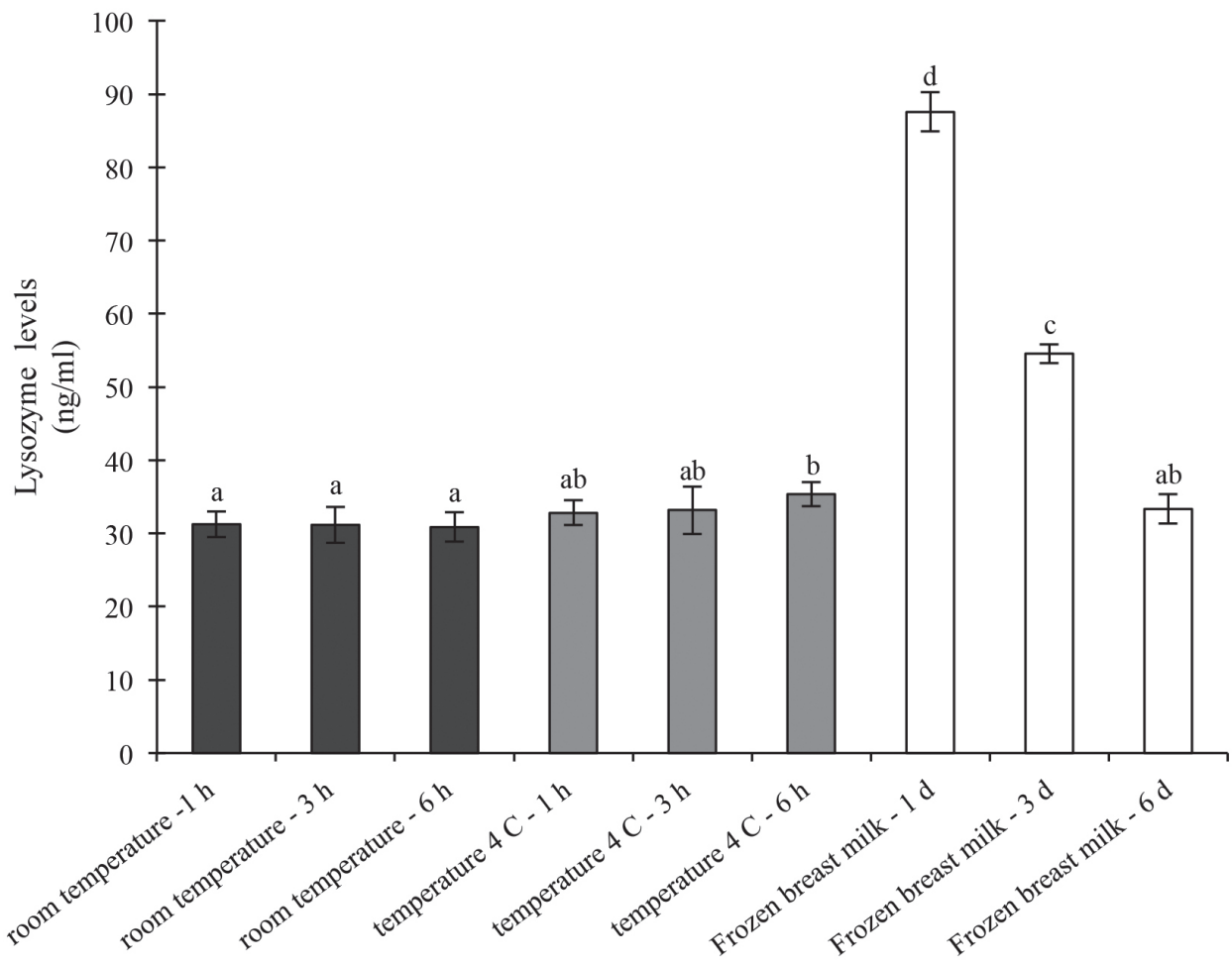

Figure 3. The levels of lysozyme in human milk at different temperatures and duration of storage time. Different letters showed significant difference compared to other groups based on DMRT post-hoc test. 


\section{CONCLUSION}

The levels of lactoferrin and lysozyme in human milk are more stable and optimal at a storage temperature of $-20^{\circ} \mathrm{C}$ (frozen human milk), which can be used to maintain their levels for the first six days. Further research is necessary to provide evidence of the antibacterial activities of lactoferrin and lysozyme in human milk at optimal storage time.

\section{Acknowledgement}

We thank the Ministry of Health, Republic of Indonesia for funding this research with grant number HK.03.01/1/1231/2020. We also thank the breastfeeding mothers at the Ponkesdes, Sumber Porong, Malang for kindly helping us to obtain human milk.

\section{Authors' contributions}

$\mathrm{K}$, principal investigator, conceptualised and designed the study, conducted the study, prepared the draft of the manuscript, reviewed the manuscript, and obtained funding; SBP was involved in data collection, prepared the draft of the manuscript, and reviewed the manuscript; ASU was involved in data collection and reviewed the manuscript; SNA assisted in data analysis and interpretation, assisted in drafting of the manuscript, and reviewed the manuscript.

\section{Conflict of interest}

Authors declare no conflict of interest.

\section{References}

Abdullah SZS \& Saleh RM (2019). Breastfeeding knowledge among indigenous Temiar women: a qualitative study. Mal J Nutr 25:117-128.

Affolter M, Garcia-Rodenas CL, Vinyes-Pares G, Jenni R, Roggero I, Avanti-Nigro O, de Castro, CA, Zhao A, Zhang Y, Wang P, Thakkar SK \& Favre L (2016). Temporal Changes of Protein Composition in Breast Milk of Chinese Urban Mothers and Impact of Caesarean Section Delivery. Nutrients 8:504-519.

Australian Breastfeeding Association (2011). Expressing and storing breastmilk [WWW Document]. Australian Breastfeeding Association. From: https://www.breastfeeding. asn.au/bf-info/breastfeeding-and-work / expressing-and-storing-breastmilk [Retrieved November 9 2020]
Basir SMA, Ghani RA, Ibrahim M, Khattak MMAK, Omar MN \& Shukri NAM (2019). Maternal diet and its association with human milk energy and macronutrient composition among exclusively breastfeeding Malaysian Malay mothers. Mal $J$ Nutr 25:309-320.

Berlutti F, Pantanella F, Natalizi T, Frioni A, Paesano R, Polimeni A \& Valenti P (2011). Antiviral Properties of Lactoferrin-A Natural Immunity Molecule. Molecules 16:6992-7018.

Bruni N, Capucchio MT, Biasibetti E, Pessione E, Cirrincione S, Giraudo L, Corona A \& Dosio, F. (2016). Antimicrobial Activity of LactoferrinRelated Peptides and Applications in Human and Veterinary Medicine. Molecules 21(6):752

Chang JC, Chen $\mathrm{CH}$, Fang LJ, Tsai CR, Chang YC \& Wang TM (2013). Influence of Prolonged Storage Process, Pasteurization, and Heat Treatment on Biologically-active Human Milk Proteins. Pediatr Neonatol 54:360-366.

Czosnykowska-Łukacka M, Orczyk-Pawiłowicz M, Broers B \& Królak-Olejnik B (2019). Lactoferrin in Human Milk of Prolonged Lactation. Nutrients 11:2350.

Eglash A, Simon L \& Academy of Breastfeeding Medicine (2017). ABM Clinical Protocol \#8: Human Milk Storage Information for Home Use for Full-Term Infants, Revised 2017. Breastfeed Med 12:390-395.

El-Agamy EI (2011). Nutrition and Health | Milk Allergy. In Fuquay JW (ed), Encyclopedia of Dairy Sciences (Second Edition) (pp. 10411045). Academic Press, San Diego.

Gálvez-Iriqui AC, Plascencia-Jatomea, M, \& Bautista-Baños S (2020). Lysozymes: characteristics, mechanism of action and technological applications on the control of pathogenic microorganisms. Rev Mex Fitopatol 38(3): 360-383

Ganz T (2006). LYSOZYME. In Laurent GJ \& Shapiro SD (eds), Encyclopedia of Respiratory Medicine (pp. 649-653). Academic Press, Oxford.

Howland V, Klaedtke M, Ruhnau J, Dhople VM, Grabe HJ, Völker U, Heckmann M \& Hammer E (2020). Impact of Storage Conditions on the Breast Milk Peptidome. Nutrients 12:2733.

Kasiati, Santoso B, Yunitasari E \& Nursalam (2013). Topikal ASI: Model Asuhan Keperawatan Tali Pusat pada Bayi. Jurnal Ners 8:9-16. 
Kim MH, Shim KS, Yi DY, Lim IS, Chae SA, Yun SW, Lee NM, Kim SY \& Kim S (2019). Macronutrient Analysis of Human Milk according to Storage and Processing in Korean Mother. Pediatr Gastroenterol Hepatol Nutr 22:262-269.

Lawrence RA \& Lawrence RM (2011) Chapter 4 - Biochemistry of Human Milk. In Lawrence RA \& Lawrence RM (eds), Breastfeeding (Seventh Edition). W.B. (pp. 98-152). Saunders, Philadelphia.

Lawrence RA \& Lawrence RM (2016). Breastfeeding: A Guide for the Medical Profession, Eighth edition. edn. Elsevier, Philadelphia, PA.

Małaczewska J, Kaczorek-Łukowska E, Wójcik R \& Siwicki AK (2019). Antiviral effects of nisin, lysozyme, lactoferrin and their mixtures against bovine viral diarrhoea virus. BMC Vet Res 15:318

Masschalck B \& Michiels CW (2003). Antimicrobial Properties of Lysozyme in Relation to Foodborne Vegetative Bacteria. Crit Rev Microbiol 29:191214.

Palmeira P, Carneiro-Sampaio M, Palmeira P \& Carneiro-Sampaio M (2016). Immunology of breast milk. Rev Assoc Méd Bras 62:584-593.

Rollo DE, Radmacher PG, Turcu RM, Myers SR \& Adamkin DH (2014). Stability of lactoferrin in stored human milk. J Perinatol 34:284-286.

Soboleva SE, Sedykh SE, Alinovskaya LI, Buneva VN \& Nevinsky GA (2019). Cow Milk Lactoferrin Possesses Several Catalytic Activities. Biomolecules 9(6):208.

Tagashira A, Nishi K, Matsumoto S \& Sugahara $\mathrm{T}$ (2018). Anti-inflammatory effect of lysozyme from hen egg white on mouse peritoneal macrophages. Cytotechnology 70:929-938.

Vázquez-Román S, Escuder-Vieco D, García-Lara NR, Alonso-Díaz C, Lora D, Martín-Pelegrina
MD \& Pallás-Alonso CR (2016). Impact of Freezing Time on Dornic Acidity in Three Types of Milk: Raw Donor Milk, Mother's Own Milk, and Pasteurized Donor Milk. Breastfeed Med 11:91-93.

Venkataramani S, Truntzer J \& Coleman DR (2013). Thermal stability of high concentration lysozyme across varying $\mathrm{pH}$ : A Fourier Transform Infrared study. J Pharm Bioallied Sci 5:148-153.

Wang B, Timilsena YP, Blanch E \& Adhikari B (2019). Lactoferrin: Structure, function, denaturation and digestion. Crit Rev Food Sci Nutr 59:580-596.

WHO (2009) Infant and Young Child Feeding: Session 2 "The Physiological Basis of Breastfeeding," Infant and Young Child Feeding: Model Chapter for Textbooks for Medical Students and Allied Health Professionals. World Health Organization, Geneva.

Yang B, Wang J, Tang B, Liu Y, Guo C, Yang P, Yu T, Li R, Zhao J, Zhang L, Dai Y \& Li N (2011). Characterization of Bioactive Recombinant Human Lysozyme Expressed in Milk of Cloned Transgenic Cattle. PLoS ONE 6(3):e17593.

Yang Z, Jiang R, Chen Q, Wang J, Duan Y, Pang X, Jiang S, Bi Y, Zhang H, Lönnerdal B, Lai, J., \& Yin, S. (2018). Concentration of Lactoferrin in Human Milk and Its Variation during Lactation in Different Chinese Populations. Nutrients 10(9): 1235 